\title{
JAGOU, Fabienne (ed.). 2018. The Hybridity of Buddhism: Contemporary Encounters between Tibetan and Chinese Traditions in Taiwan and the Mainland. Paris: École française d'Extrême-Orient.
}

Zhe Ji

Translator. N. Jayaram

\section{OpenEdition}

\section{Journals}

\section{Electronic version}

URL: http://journals.openedition.org/chinaperspectives/9763

DOI: 10.4000/chinaperspectives.9763

ISSN: 1996-4617

\section{Publisher}

Centre d'étude français sur la Chine contemporaine

\section{Printed version}

Date of publication: 1 December 2019

Number of pages: $56-57$

ISSN: 2070-3449

\section{Electronic reference}

Zhe Ji, "JAGOU, Fabienne (ed.). 2018. The Hybridity of Buddhism: Contemporary Encounters between Tibetan and Chinese Traditions in Taiwan and the Mainland. Paris: École française d'Extrême-Orient.", China Perspectives [Online], 2019-4 | 2019, Online since 01 December 2019, connection on 30 March 2021. URL: http://journals.openedition.org/chinaperspectives/9763 ; DOI: https://doi.org/10.4000/ chinaperspectives.9763

This text was automatically generated on 30 March 2021.

(C) All rights reserved 


\section{JAGOU, Fabienne (ed.). 2018. The Hybridity of Buddhism: Contemporary Encounters between Tibetan and Chinese Traditions in Taiwan and the Mainland. Paris: École française d'Extrême-Orient.}

Zhe Ji

Translation : N. Jayaram

1 Taiwan is a heaven of religions, for both practitioners and scholars. The island, separated from the mainland since the late nineteenth century, has been able to repel the influence of the Chinese-speaking world's radical secularist movements throughout the twentieth century, from the May 4th movement to the Cultural Revolution. After 1949, the arrival of a large number of major religious representatives of different traditions from the mainland boosted the island's religious diversity. During the years 1980-1990, with democratisation, economic growth, and the emergence of large independent organisations and new movements, Taiwan attained a new stage of religious differentiation and pluralism. In the early twenty-first century, Taiwan - where the mainsprings of many networks of transnational religions are active has become the spearhead for Chinese religions' globalisation.

2 As for Buddhism, while much has been written about organisations in the Humanistic Buddhism line such as Foguang shan 佛光山 and Tzu Chi 慈濟, Tibetan Buddhism in Taiwan has been insufficiently studied, especially in Western languages, despite its importance. This collection edited by Fabienne Jagou, associate professor at the École française 
d'Extrême-Orient (French School of the Far East), has filled the void by analysing the tradition's spiritual, cultural, ethnic, and political issues, and politics in religious remaking in Taiwan, and more generally in the contemporary Chinese-speaking world. Resulting from the international project Practices of Tibetan Buddhism in Taiwan (2012-2015), this volume gathers contributions from six European and two Taiwanese scholars.

3 In her introduction, after a brief review of existing scholarship, Fabienne Jagou retraces the political and historical processes leading to Tibetan Buddhism's growth through several key dates such as the arrival of the first exiles during the years 1949-1950 and of Tibetan masters in 1980, the lifting of Martial Law in 1987, and the introduction of freedom of association in 1989. These political transformations were punctuated by the Dalai Lama's visits in 1997, 2001, and 2009, leaving a not insignificant impact on Tibetan Buddhism's reconfiguration in Taiwan. Jagou then offers an analysis of "hybridity," a central concept common to the studies presented. This hybridity shows up at several levels. It of course includes interactions between Tibetan and Chinese Buddhism, not ignoring elements of other origins, and also encompasses linguistic, aesthetic, liturgical, and identity mixtures. Taiwan's special position at the frontiers of the Chinese-speaking world favours this hybridity, facilitating a transformation and acculturation of Tibetan Buddhism.

4 The next eight chapters may be divided into three parts. The first three chapters present the general situation of Tibetan Buddhism in Taiwan, with a sociological as well as spatial and historic perspective. Cécile Campergue offers a highly informative panorama on schools, centres, practitioners, and activities based mainly on official data and on a study through questionnaires conducted during her sojourn. She reveals that during the previous decade, 600,000 people embraced Tibetan Buddhism (2006), that 238 practice centres operate in Taiwan (2005), and that each year 200 visas are issued to Tibetan monks. She also offers comparisons between Tibetan Buddhism in Taiwan and its Western counterpart. Sarah E. Fraser, in her chapter, notes that the Dalai Lama's 1997 visit marked a transformation in the architectural style of Tibetan Buddhist centres. While those established between 1949 and 1997 were rather discreet and situated in residential areas, new monasteries founded after 1997 adopted a more Himalayan style, featuring imported and ornate objects. The exhibition of these religious treasures in a public space reflects an attempt at legitimation and diffusion of Buddhism through the adoption of authentic religiosity. By retracing the lives of Changkya Qutu tu Lozang Penpé Drönmé (1891-1957) and Gongga Laoren (1903-1997), Tibetan Buddhism's two key figures, Jagou sheds light on the history of Tibetan Buddhism's implantation in Taiwan and on the practices that unite Tibetan and Chinese traditions. Information such as the conduct of funerals and 
veneration of relics helps understand how the links between the past and present of Tibetan Buddhism in Taiwan have been built.

5 The next three chapters each deal with a specific Tibetan Buddhist school. Cody R. Bahir's chapter focuses on the "Zhenyan school revival" phenomenon, relating to an esoteric Buddhist form that had its golden age during the Tang dynasty and was introduced in Japan as Shingon. The case is typical of the religious reinvention and hybridity it engenders: the legitimacy of current Zhenyan school leaders stems from both their lineage in Japanese Shingon and their inscription in Tibetan Buddhism's transmission. Ester Bianchi offers a study of the diffusion of teachings from the dzokchen at Larung Gar among Chinese people in the mainland and Taiwan, with the help of the noted Larung Gar Five Sciences Buddhist Academy at Sertar (Sichuan). According to her, this current's extraordinary influence among Han Chinese is due to the cumulation of several individual and contextual factors: relatively tolerant local political conditions, the organisation's accessibility and flexibility, Tibetan masters' inclusive attitude towards Chinese Buddhist traditions, and their ability to teach in Chinese and use modern media. Magdalena Maria Turek's contribution is not directly related to Taiwan, but focuses on the post-Mao revival of the Barom Kagyü school in Kham. The author analyses the Tibetan masters' strategies for reconstructing their school's continuity, specially noting the engagement of Han Chinese in the movement and the impact of transnational Buddhist networks.

6 The book's last two chapters are devoted to the master as individual. As Jagou notes in her introduction, Tibetan Buddhism's hybridity in Taiwan would have been inconceivable without the efforts of charismatic masters and the incarnated imagination they represent. Huang Yingchieh's case study concerns the transmission of Buddhist teaching through the oracular activities of a Chinese master before he was official recognised as master of the Karma Kagyü school in 1992. Hsiao Chin-sung presents a biographical study of his master Ouyang Wuwei (1913-1991), who studied Buddhism in Tibet from 1934 to1951 and later founded Tibetan studies in Taiwan.

7 These histories enhance understanding of Tibetan Buddhism's vitality, diversity, and creativity in the Chinese-speaking world. Certainly, there remains a vast terrain to explore, for instance groups that do not claim to adhere to Tibetan Buddhism but integrate Tibetan texts and rituals in their practice. Despite the chapters' variety in terms of style and application of the "hybridity" concept, the book makes an important contribution to both Taiwanese studies and studies of Tibetan Buddhism, relying on rich ethnographic material and multi-level approaches. With "hybridity," this work reminds us that a religion's trans-ethnic expansion entails adaptations and innovations, and that any attachment to a pure, immutable, and exclusive identity is but an illusion. 


\section{AUTHORS}

ZHE JI

Zhe Ji is professor of sociology, Department of Chinese Studies, Inalco, Paris,

France.zhe.ji@inalco.fr 